\title{
Parental Involvement on Students' Learning Abilities and Achievement in the English Subject
}

\author{
A. M. Sultana and Nuraini Binti Rosli
}

\begin{abstract}
At present in the trend of globalization, the English language has become the most important language that is used all over the world. Similarly, English subject is becoming a central concern in various universities and academic institutions in Malaysia. The article attempts to investigate factors influence on students' learning achievement in the English subject in secondary school. A total of 50 students from SMK Sultan Abdul Samad, Banting were selected as the respondents for the study. Students' responses towards their family supports were measured using a four point Likert scale. To determine the relationship between family role and student learning achievement, the correlation coefficient was conducted and the results revealed that only parents' education has a significant $(p=0.05)$ relationship to students' academic achievement. By giving the importance of the knowledge in English subject for educational, economic and national development of a country several suggestions are made.
\end{abstract}

Index Terms-Academic achievement, home environment, parental involvement.

\section{INTRODUCTION}

The present article attempts to investigate factors influence on student learning achievement in the English subject in secondary school from the Malaysian perspective. In the increasingly reliant world, the English language is seen only as an added advantage medium which is important in accessing foreign technology. It is also a systematic association with someone's engagement in politics, security, global trade and education [1]. English would contribute to the standard of living of a any nation. The article focuses on student's learning achievement in the English in educational institution in Malaysia that would contribute to standard of living as well as the effective learning. In Malaysia English is essential to become a developed country. Therefore, Malaysia has given emphasized on the importance of learning English language, particularly for students in order to develop the human capital that would enable to compete in the international arena as well as to become a developed country [1]. English has also been given emphasized by educational leaders in order to foster foreign language competency among students [2]-[5].

Although English is given high priority on the aspect of achieving the standard of living as well as moving towards a developed nation, there is a growing concern whether students have sufficient proficiency in English in educational institutions in Malaysia. It was reported that

Manuscript received August 5, 2014; revised October 16, 2014.

The authrors are with Department of Social Studies and Citizenship, Faculty of Human Sciences, Universiti Pendidikan Sultan Idris, 35900 Tanjong Malim, Perak, Malaysia (e-mail: sultana@fsk.upsi.edu.my).
Malaysia is facing challenges related to unemployment problem among graduates due to lack of communication skill, poor command of English and lack of work experience. About 60,000 Malaysian graduates are unemployed and lack of skill in English is found one of the important factors that contribute to unemployment problem in Malaysia [6].

However, with respect to the increasing demand for learning English among students at their educational institutions, there is a necessity to conduct research in this area. The present article, therefore, investigates the family related factors and parental involvement in student's achievement in the English subject. The family and parent's role have an important contribution towards student's academic achievement. The family makes critical contributions to a child's achievement from early childhood through high school. In a study on English adolescents' competence at and commitment to physical education, Carr and Hussey [7] found that parents were the most influential social agents on children's task orientations, intrinsic motivation and physical competence. In another study, it was noted that most parents see the major limits to further involvement to arise from their own limitations, especially in respect of time available [8], [9].

However, most of the literatures in the educational and psychological research found parental involvement as the significant impacts on students' learning and developmental processes. Some studies found parental expectations as the stem from their beliefs and practices have been a dominant predictor of students' learning achievement [10]. However, there is also an argument that the nature and extent of parental involvement at home and at school play a crucial role in the development of their children's academic potential [11]. Therefore, it is noted that the relationship between parental affective values such as parents' expectations and involvement are important for students' achievement in the English subject. From these circumstances, the study attempts to determine parental involvement on student's learning abilities and achievement in English subject from the Malaysian perspective. This study would provide an insight on how parental encouragement, motivation and involvement are necessary for children's highest achievement in the English subject as well the greater prosperity of the country.

\section{Objectives AND ReSEARCh Design}

The objectives of this study are 1) to examine the parental involvement on student's learning abilities and achievement in the English subject. 2) to identify the relationship between socioeconomic factors and students' leaarning achievement in the English subjects. The study was 
conducted at SMK Sultan Abdul Samad in the district of Banting, Selangor. This study was basically quantitative in nature. Data was collected by using questionnaires. Questionnaires were handed to each respondent and the information was collected directly by the researchers. Data was analyzed using Statistical Software Packages for the Social Sciences (SPSS). A total of 50 students from SMK Sultan Abdul Samad, Banting were selected as the respondents for the study. Family background included parents' education levels, parents' occupations, family socioeconomic status; family size, family structure and home environment have been selected as the independent variables in this article. Students' responses towards their family supports were measured using a four point Likert scale. Since this was a descriptive study frequency, standard deviation, mean and percentages, correlation, minimum and maximum value were largely used in this study.

To determine the relationship between family role and student learning achievement, the correlation coefficient was also conducted. Based on the discussion above, the article developed a framework that is shown in Figure 1. The dependent variable of this study is student's achievement in the English subject while the independent variables are family background, family size, family socio-economic condition and family environment. The independent variables can be explained as follows:

- Family background: refer to the level of parental education, parental employment, and family structure.

- Family size: refer to the number of children in the family/number of sibling and respondents position among siblings.

- Family socioeconomic: refer to parental income and family social status in society.

- Family environment: refer to family surrounding, parental encouragement and facilities at home.

Dependent Variable Independent Variables

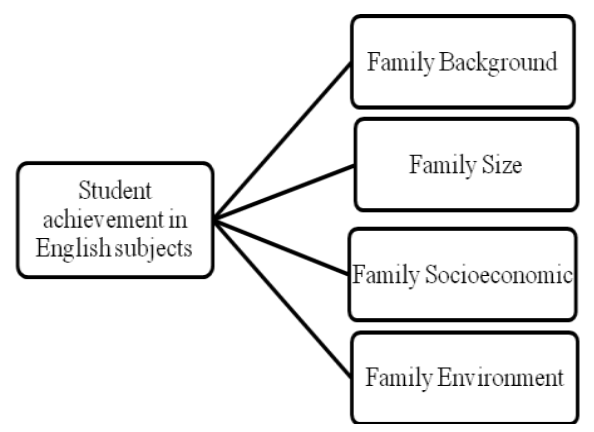

Fig. 1. Research framework.

The Fig. 1 shows that student's learning achievement is dependent variable which may depend on the the selected independent variables such as family background, family size, socioeconomic condition of the family and family environment.

\section{RESULTS AND DiSCUSSION}

\section{A. Parental Encouragement and Supports on Student's Learning Abilities and Achievement}

Before analyzing parental encouragement and supports on students' learning abilities and achievement, it is important to provide a short explanation of demographic profile of the respondents. The data results revealed that the highest number of respondents were Chinese $(38 \%)$, the second highest were Indian $(36 \%)$ and the third highest were Malay $(22 \%)$ respectively. There were only a few $(4 \%)$ respondents originated from Sabahan ethnic group. Although the majority of the people in Malaysia are Malay, the results showed that the majority of respondents in this article are Chinese. This is one of the reason for the low number of Malay students' introversion attitudes which have been observed during data collection. Chinese and Indian students were found more co-operative than the Malay students.

TABLE I: MEASURING PARENTS' ENCOURAGEMENTS AND SUPPORT

\begin{tabular}{|c|c|c|c|c|c|c|}
\hline Item & $1(\%)$ & $2(\%)$ & $3(\%)$ & $4(\%)$ & $\mathrm{M}$ & SD \\
\hline $\begin{array}{l}\text { My parents always } \\
\text { talked to me about my } \\
\text { learning English } \\
\text { Subject }\end{array}$ & 20.0 & 54.0 & 20.0 & 6.0 & 2.12 & 0.79 \\
\hline $\begin{array}{l}\text { My parents always talk } \\
\text { to the teacher about my } \\
\text { progress in school }\end{array}$ & 58.0 & 26.0 & 6.0 & 10.0 & 2.72 & 0.73 \\
\hline $\begin{array}{l}\text { My parents upset if I } \\
\text { do not perform well in } \\
\text { the English subject }\end{array}$ & 32.0 & 38.0 & 22.0 & 8.0 & 2.06 & 0.93 \\
\hline $\begin{array}{l}\text { My parents always } \\
\text { encourage me saying } \\
\text { that I have to do better } \\
\text { in the English subject }\end{array}$ & 54.0 & 42.0 & 2.0 & 2.0 & 1.52 & 0.65 \\
\hline $\begin{array}{l}\text { My parents have a } \\
\text { higher expectation in } \\
\text { English subject than } \\
\text { other subject }\end{array}$ & 42.0 & 48.0 & 10.0 & 0.0 & 1.68 & 0.65 \\
\hline $\begin{array}{l}\text { My parents always help } \\
\text { me with my homework } \\
\text { and check my exercise } \\
\text { books }\end{array}$ & 12.0 & 28.0 & 50.0 & 10.0 & 2.58 & 0.83 \\
\hline $\begin{array}{l}\text { My parents always give } \\
\text { me emotional and } \\
\text { moral support to do the } \\
\text { best in the English } \\
\text { subject }\end{array}$ & 10.0 & 28.0 & 50.0 & 12.0 & 2.64 & 0.83 \\
\hline $\begin{array}{l}\text { My parents are always } \\
\text { involved themselves in } \\
\text { my subject activity }\end{array}$ & 28.0 & 64.0 & 6.0 & 2.0 & 1.82 & 0.63 \\
\hline $\begin{array}{l}\text { Mean }=2.35 \\
\text { Indication } \\
\text { 1) Strongly agree, 2) Ag } \\
\text { M: Mean, SD: Standard }\end{array}$ & \multicolumn{6}{|c|}{ Standard Deviation $=0.41$} \\
\hline
\end{tabular}

However, a major purpose of this study is to determine parental involvement and support as the important factors that influence on student's learning achievement in the English subject. Parental involvement has been identified as positively impacting students' learning abilities and achievement [12]. A growing literature showed that parental involvement has an influence on student's behaviors, school attendance and lower dropout rates [13], [14]. Although some studies found positive impact of parental involvement on student's academic success, the study of this aspect has still been limited. In line with this background, the study attempted to examine parental encouragement and support on student's learning and achievements in the English subject. As mentioned elsewhere, a Likert scale has been used to determine parental encouragement and supports on student's learning abilities and achievement. The variables 
were measured using 8 statements by using a four point Likert format. The results are presented in Table I showed that most of the students agree (20\%) and strongly agree $(54 \%)$ that their parents always talked to them about their learning progress in the English Subject. Similarly, in the second statement "My parents always talk to the teacher about my progress in school" most of the students agree $(58 \%)$ and strongly agree $(26 \%)$ respectively. Moreover, parents are found in anxiety when their children do not perform well in the English subject (Mean=2.06). The majority (Mean=1.52) of the students agreed with the statement that "My parents always encourage me saying that I have to do better in the English subject" which shows stronger positive attitude of the student's parents towards their children's learning in the English subject.

A significant parental involvement and encouragement were found in the next statement where most of the students (Mean=1.68) agreed that their parents have a higher expectation in the English subject than other subject. Parental involvement and encouragement were found as the significant impact towards student's learning abilities and achievement in the English subject. A growing literature also found parental expectations as a dominant predictor of students' learning abilities and achievement [15], [16]. Furthermore, some studies found parental expectations on their children's ability and talent are paramount in promoting the potential for the children's academic achievement [17], [18].

Although in the earlier results, a significant parental involvement and encouragement were found, some students (50.0\% disagree and $12.0 \%$ strongly disagree) expressed opposite opinion on the statement that their parents always give them emotional and moral support to do the best in the English subject. Mean and standard deviation are recorded for this statement 2.64 and 0.83 respectively. These results showed that most of the students did not receive emotional and moral supports from their parents. A general perception and literatures considered emotional and moral supports from their parents are as the vital for achieving student's success in the English subject. It is also noted that even the high-ability students would achieve the success when they get emotional and social support and encouragement from their parents [19]. Similarly, the majority of the students (Mean=1.82) stated that their parents always involved in their subject activity at home, which could be considered as the positive parental encouragement and involvement. Parental participation improves student learning whether the child is in preschool or in the upper grades. This article also contributed to show that the positive parental encouragement and involvement that noted in the majority of the respondent's opinions.

\section{B. Determining the Factors that Influence on Student's Learning Achievement in the English Subject}

This section analyzed to what extent factors influence on students' learning abilities and achievement in the English subject. Extensive literature revealed a positive link between parental involvement and students' achievement motivation and attitudes [20]. However, there are other factors such as family environment, reading facilities at home, family surrounding and family environment may influence on student learning achievement. In order to determine the influence of socio-demographic factors and student's learning success in the English subject, correlation coefficient (r) was measured by using statistical analysis. Although the extensive literature support that parental involvement has been identified as positively impacting students' learning abilities and achievement [10]-[12] the present study showed that there is a negative relation between parental encouragement and student's learning abilities and achievement in the English subject. Similarly, other factors such as PMR for English subjects reading facilities at home, family surrounding and family environment are found as the negative influence on student learning achievement in the English subject. The article also revealed that parents' socioeconomic condition may not important, but the level of parental involvement and motivation may influence on student achievement in the English subject.

TABLE II: RELATIONSHIP BETWEEN DEMOGRAPHIC FACTORS AND STUDENT'S LEARNING ACHIEVEMENT

\begin{tabular}{lccccc}
\multicolumn{5}{c}{ STUDENT'S LEARNING ACHIEVEMENT } \\
$\begin{array}{l}\text { Pearson } \\
\text { Correlation }\end{array}$ & $\begin{array}{c}\text { PMR } \\
\text { results }\end{array}$ & $\begin{array}{c}\text { Parents } \\
\text { Encourage- } \\
\text { ment }\end{array}$ & $\begin{array}{c}\text { Physical } \\
\text { facilities }\end{array}$ & $\begin{array}{c}\text { Family } \\
\text { Surrou } \\
\text { nding }\end{array}$ & $\begin{array}{c}\text { Family } \\
\text { Environ- } \\
\text { ment }\end{array}$ \\
\hline $\begin{array}{l}\text { PMR } \\
\text { results }\end{array}$ & 1.000 & & & & \\
\hline $\begin{array}{l}\text { Parents } \\
\text { encourage- } \\
\text { ment }\end{array}$ & -.049 & 1.000 & & & \\
\hline $\begin{array}{l}\text { Physical } \\
\text { facilities }\end{array}$ & -.099 & $.447^{* *}$ & 1.000 & & \\
\hline $\begin{array}{l}\text { Family } \\
\text { Surround- } \\
\text { ing }\end{array}$ & -.069 & .217 & $.285^{*}$ & 1.000 & \\
\hline $\begin{array}{l}\text { Family } \\
\begin{array}{l}\text { Environ- } \\
\text { ment }\end{array}\end{array}$ & -.092 & $.833^{* *}$ & $.757^{* *}$ & $.603 * *$ & 1.000 \\
\hline
\end{tabular}

**Correlation is significant at the 0.01 level

*Correlation is significant at the 0.05 level

Hence, the relationship that exists between parental affective values such as parents' expectations and involvement and their belief in their children's ability to achieve, especially in high-ability students, warrants further investigation. Furthermore, the nature and extent of parental involvement at home and at school play a crucial role in the development of their 'children's academic potential [21], [22].

\section{CONCLUSION AND RERECOMMENDATIONS}

The article investigated parental involvement on students' learning abilities and achievement in the English Subject. The extensive literature support that parental involvement has been identified as positively impacting students' learning abilities and achievement. In order to measure parental encouragement and supports on student's learning abilities and achievement, a total of eight statements were used and the results revealed the positive parental encouragement and involvement that noted in the majority of the respondent's responses. Although through results extracted using a Likert Scale showed parental involvement positively impacting students' learning abilities and achievement, the correlation results showed a negative relation between parental encouragement and student's 
learning abilities and achievement in the English subject. This might be one of the reasons is that this study conducted with a small number of respondents. Thus the findings of the study may not be generalized to all aspects in Malaysia. A similar study should be conducted to include a larger number of respondents in the various states in Malaysia. This would help in finding whether parental encouragement and supports necessary for the student's abilities and achievement in the English subject. Morever, there are other factors such as educational institution would play an important role for student's achievement in the English subject.

However, the English Language has a significant role of becoming a developed nation. English as the second language in Malaysia, students' English proficiency is necessary. The previous Prime Minister, Tun Abdullah bin Haji Ahmad Badawi said (speech at the Teacher's Day in 2002);

"We must accept the fact that in the era of globalization overcome of at least one major foreign language is very useful for improving the ability to gain knowledge in various of fields such as science, technology, including ICT, and enhancing the role of the broader and effective international relations."

Although the importance of English, especially among students is duly acknowledged, Malaysian students' display poor effort in learning English [23]. Although there are several factors may influence on student's learning attitudes towards English subject, parental encouragement and motivation are certainly important. It was also found that motivated students have positive attitudes towards learning English [24].

Given the importance and demands of parental motivation and encouragement on students' learning achievement in the English subject, the article suggests that the government of Malaysia would take necessary steps to increase parents' awareness about the importance of motivating their children in the English subject. This effort would increase students' learning abilities and achievement in the English subject. This will also help students to further their studies, career advancement and overall development of the country.

\section{REFERENCES}

[1] A. M. Zubairi, "Motivation to learn a foreign language in Malaysia," GEMA Journal of Language Studies, pp. 73-86, 2009.

[2] P. Zeszotarski, "ERIC review: issues in global education initiatives in the community college," Community College Review, vol. 29, pp. 65$72,2001$.

[3] E. B. Welles, "Foreign language enrollments in united states institutions of higher education, Fall 2004," ADFL Bulletin, vol. 35 , pp. 73-95, 2004.

[4] P. Christian and N. Rhodes, "Fostering foreign language proficiency: what the US can learn from other nations," Phi Delta Kappan, vol. 87 no. 3, pp. 226-228, 2005.

[5] A. M. Zubairi, I. H. Sarudin, and M. S. Nordin, "A study of the effectiveness of foreign language programs in Malaysia," in Proc. the 32nd Annual Congress of the Applied Linguistics Association of Australia, Making a Difference: Challenges for Applied Linguistics, University of Wollongong, 2007.

[6] Economic Planning Unit, Malaysia. Department of Prime Minister, $\begin{array}{lll}\text { Malaysia. } & \text { (2009). }\end{array}$ http://www.epu.gov.my/malaysianeconomyfigures 2009

[7] S. Carr, D. A. Weigand, and W. Hussey, "The relative influence of parents, teachers, and peers on children and adolescents' achievement and intrinsic motivation and perceived competence in physical education," Journal of Sport Pedagogy, vol. 5, no. 1, pp. 28-50, 1999.

[8] A. Anning, "New deals and old dilemmas: lone parents of young children balancing work and parenthood," presented at the British Educational Research Association Annual Conference, Cardiff, September, 2000.

[9] K. Standing, "Lone mothers and parental involvement: a contradiction in policy?" The Journal of Social Policy, vol. 28, no. 3, pp. 479-495, 1999.

[10] S. Phillipson and S. N Phillipson, "Academic expectation, belief of ability and involvement by parents as predictors of child achievement: a cross cultural comparison," Educational Psychology, vol. 27, no. 3, pp. 329-348,2007.

[11] F. J. Morrison, "Parenting and academic development," MerrillPalmer Quarterly, vol. 55, no. 3, pp. 361-372, 2009

[12] C. Desforges and A. Abuchaar, "The impact of parental involvement, parental support and family education on pupil achievement and adjustment: a literature review," Department of Education and Skills Development, vol. 31, no. 6, pp. 594-602, 2003.

[13] T. Domina, "Leveling the home advantage: assessing the effectiveness of parental involvement in elementary school," Sociology of Education, vol. 78, pp. 233-249, 2005.

[14] B. S. Simon, "Family involvement in high school: predictors and effects," NASSP Bulletin, vol. 85, pp. 8-19, 2001.

[15] R. W. Rumberger, "Dropping out of middle school: a multilevel analysis of students and schools," American Educational Research Journal, vol. 32, pp. 583-625, 1995.

[16] M. P. Neuenschwander, M. Vida, J. L. Garret, and J. Eccles, "Parents' expectations and students' achievement in two western nations," International Journal of Behavioral, 2007.

[17] S. Phillipson and S. N. Phillipson, "Academic expectation, belief of ability and involvement by parents as predictors of child achievement: A cross-cultural comparison," Educational Psychology, vol. 27, no. 3 , pp. 329-348, 2007.

[18] D. W. Chang, "Dimensionality and typology of perfectionism: the use of the frost multidimensional perfectionism scale with Chinese gifted students in Hong Kong," Gifted Child Quarterly, vol. 53, no. 3, pp. 174-187, 2009.

[19] A. Furnham, T. Rakow, and T. Mak, "The determinants of parents' beliefs about the intelligence of the children: a study from Hong Kong,"International Journal of Psychology, vol. 37, no. 6, pp. 343$352,2002$.

[20] A. Morawska and M. R. Sanders, "Parenting gifted and talented children: What are the key child behavior and parenting issues?" Australian and New Zealand Journal of Psychiatry, vol. 42, no. 9, pp. 819-827, 2008.

[21] A. R. G. Dehass, P. P. Willems, and M. F. D. Holbein, "Examining the relationship between parental involvement and student motivation," Educational Psychology Review, vol. 17, pp. 99-123, 2005.

[22] T. L. Clemons, "Underachieving gifted students: a social cognitive model," PhD dissertation, University of Virginia, Charlottesville, VA, USA, 2005.

[23] F. J. Morrison, "Parenting and academic development," MerrillPalmer Quarterly, vol. 55, no. 3, pp. 361-372, 2009.

[24] S. M. Thang, S. L. Ting, and M. J. Nurjanah, "Attitudes and motivation of Malaysian secondary students towards learning English as a second language: a case study," The Southeast Asian Journal of English Language Studies, vol. 17, no. 1, pp. 40-54, 2011



M. Sultana Alam is currently a senior lecturer in the Department of Social Studies and Citizenship, Faculty of Human Science, Universiti Pendidikan Sultana Idris, Malaysia. She completed the degree of bachelor of arts in history, Department of History, University of Rajshahi, Bangladesh in October 1998 She obtained the master of Arts in History, Department of History, University of Rajshahi, Bangladesh on December 1999. The author enrolled as a full-time candidate for $\mathrm{PhD}$ program in the field of Community Development, Department of Social and Development Sciences, Faculty of Human Ecology, Universiti Putra Malaysia (UPM), Malaysia in November 2002. She completed her PhD in April, 2006. She has published various articles in refereed journals. Currently, she is also a reviewer and associated editor in the peer reviewed journals. She has been a principle researcher on various projects related to women and gender issues her areas of research interest include women education and empowerment, work family conflict, child development, gender and development. 